\title{
PEMBINAAN KEROHANIAN GEREJA BETHEL TABERNAKEL DALAM KONTEKS KEBUDAYAAN TORAJA
}

\author{
Yonatan Sumarto \\ Peter Anggu \\ Sekolah Tinggi Filsafat Theologia Jaffray
}

\begin{abstract}
ABSTRAK
Penulisan ini bertujuan untuk menambah wawasan dan mengembangkan pola pikir para hamba Tuhan yang melayani di Tana Toraja mengenai keberadaan dan fungsinya di tengah-tengah masyarakat Toraja yang masih terikat pada adat dan kebudayaannya. Manfaat lain dari tulisan ini adalah sebagai suatu acuan dan tuntunan praktis bagi para hamba Tuhan dalam GBT khususnya yang melayani di Tana Toraja, untuk mendiskusikan lebih lanjut tentang cara memanfaatkan kebudayaan suku Toraja, agar dapat menemukan suatu cara yang lebih efektif untuk pembinaan rohani GBT pada masa sekarang dan yang akan datang.

Sejalan dengan permasalahan dan tujuan penulisan ini, penulis mengadakan penelitian yang difokuskan pada konteks kebudayaan Toraja, untuk mengetahui dan mengkontekstualisasikan elemenelemen yang positif dalam kebudayaan suku Toraja untuk pembinaan kerohanian GBT di Tana Toraja. Pengumpulan data dilakukan dengan dengan metode analisis, yaitu mengadakan observasi dan interview serta studi literatur pada perpustakaan.

Hasil penelitian menggambarkan bahwa ternyata di dalam berbagai kebudayaan suku Toraja terdapat unsur-unsur kebudayaan yang dapat dikontekstualisasikan untuk pembinaan rohani GBT karena bersifat netral terhadap iman Kristen, tetapi ada pula yang tidak dapat dikontekstualisasikan karena bertolak belakang dengan iman Kristen. Kebudayaan yang dapat dikontekstualisasikan, seperti konsep penyembahan kepada Puang Matua dan kepada tiga oknum Allah, upacara rambu tuka', upacara rampanan kapa', pemali-pemali (larangan), tongkonan, sikap gotong-royong, dan saling memberi. Kebudayaan yang tidak dapat dikontekstualisasikan, seperti penyembahan kepada banyak dewa dan kepada arwah nenek moyang, kurban kepada orang mati, patung sebagai pengganti orang mati (tau-tau), upacara rambu solo', ma'badong. Namun, hal ini tidak lepas dari masalahmasalah karena iman percayanya kepada Yesus Kristus. Tetapi sebagai gereja/orang Kristen yang sungguh-sungguh berpegang teguh pada Firman Allah, tidak akan gentar menghadapi semuanya itu, bahkan semakin memiliki iman Kristiani yang kokoh.
\end{abstract}

Kata kunci: Pembinaan kerohanian, kebudayaan, suku Toraja

\section{Latar Belakang}

\section{PENDAHULUAN}

Dewasa ini Gereja Bethel Tabernakel di Tana Toraja sulit merumuskan dan membedakan aluk (Agama), adat dan kebudayaan sehingga mengakibatkan penafsiran, penghayatan dan pengamalan yang berbeda-beda. Situasi yang dihadapi oleh Gereja Bethel Tabernakel di Tana Toraja dewasa ini terletak pada pemahaman dan hubungan antara aluk dan adat. Ada gereja-gereja yang cenderung memisahkan aluk dan adat, ada pula yang tetap mempertahankan bahwa aluk dan adat merupakan dua hal yang berhubungan dan tak terpisahkan. Masing-masing memiliki keputusan yang kadangkadang berlainan satu dengan yang lain. Satu contoh mengenai pemotongan hewan pada pesta kematian (tunuan tomate), ini adalah pengorbanan berupa hewan untuk orang mati dalam kaitannya dengan upacara kematian di Tana Toraja. Orang Toraja yang masih berpaham Aluk Todolo beralasan bahwa orang yang meninggal dunia dan tidak dipotongkan hewan, arwahnya tidak akan diterima masuk puya (dunia roh). Ada pula yang berpendapat bahwa hewan yang dipotong pada waktu upacara kematian, akan dibawah sebagai bekal dan akan digunakan di puya. Sebab itu, bagaimana pun juga harus diusahakan. 
Gereja-gereja yang memisahkan antara aluk dan adat, berpendapat bahwa pemotongan hewan pada pesta kematian itu tidak dilarang, asalkan unsur aluknya dikeluarkan berarti tinggal unsur adatnya. Sebagai orang Toraja adat tidak boleh diabaikan, karena menyangkut longko Toraya (harga diri). Dalam hal ini, pemotongan hewan secara besar-besaran pada pesta kematian, dipandang hanya sebagai adat yang sulit hilang dari kehidupan orang Toraja dan dipandang tidak bertentangan dengan Firman Allah. Akan tetapi gereja-gereja yang berpendapat bahwa aluk dan adat tidak dapat dipisahkan karena saling berkaitan, sama sekali menganggap bahwa pemotongan hewan pada pesta kematian itu tidak sesuai dengan Firman Allah, mengingat latar belakang pemotongan hewan yang telah dikemukakan sebelumnya.

Dalam kebudayaan Toraja ini tersirat hal-hal negatif. Jadi perlu diakui bahwa tidak semua kebudayaan Toraja dapat digunakan untuk pembinaan rohani gereja dalam upaya pendewasaan rohani jemaat.

Seyogyanya kebudayaan mempunyai fungsi membina kehidupan rohani gereja dalam upaya pendewasaan rohani jemaat, namun pada kenyataannya tidak semua kebudayaan Toraja dapat digunakan untuk pembinaan rohani gereja dalam upaya pendewasaan rohani jemaat. Unsur-unsur kebudayaan Toraja ada yang dapat dikontekstualisasikan dalam rangka pembinaan rohani gereja dan ada yang tidak dapat dikontekstualisasikan karena bertentangan dengan ajaran Kristen. Yang menjadi dasar bagi setiap hamba Tuhan dalam mengkontekstualisasikan kebudayaan Toraja adalah Firman Allah dan kuasa Roh Kudus.

Kebudayaan suku Toraja adalah identitas dan pola hidup orang Toraja. Oleh karena itu, unsur-unsur dalam kebudayaan Toraja perlu dipahami secara mendalam, sebab unsurunsur dalam kebudayaan ini ada yang bersifat menentang kebenaran Firman Allah, ada yang bersifat netral dan ada pula yang segaris dengan Firman Allah. Yang menentang Firman Allah harus ditinggalkan, sementara yang netral dan yang segaris dengan Firman Allah dapat dikontekstualisasikan dengan cara membaharui dan menguduskannya di bawah ketaatan kepada Firman Allah agar bertujuan untuk memuliakan nama Tuhan. Suatu unsur budaya absah dalam penggunaanya bagi kontekstualisasi pembinaan rohani gereja, apabila tujuannya ialah untuk memperkenalkan Kristus kepada dan ke dalam konteks suatu budaya. ${ }^{1}$

\section{Rumusan Masalah}

Adat dan kebudayaan yang ada dalam suku Toraja merupakan suatu fenomena yang menarik untuk dikaji dalam kaitannya dengan pembinaan rohani gereja-gereja di Tana Toraja. Aluk, adat dan kebudayaan suku Toraja merupakan satu kesatuan yang kaitmengait dan sulit dipisahkan satu dari yang lain. Itulah sebabnya dewasa ini gereja-gereja di Tana Toraja sulit merumuskan dan membedakan aluk (Agama), adat dan kebudayaan sehingga mengakibatkan penafsiran, penghayatan dan pengamalan yang berbeda-beda. Dengan fakta ini, maka yang menjadi masalah pokok dari penelitian ini, adalah sebagai berikut: Pertama, sejauh mana unsur-unsur yang negatif dalam kebudayaan suku Toraja ditiadakan dan sejauh mana unsur-unsur yang positif dikembangkan? Kedua, bagaimana cara mengkontekstualisasikan kebudayaan Toraja bagi pembinaan rohani dalam Gereja Bethel Tabernakel di Tana Toraja?

\section{Tujuan Penulisan}

Pertama, untuk melihat sejauh mana unsur-unsur yang negatif dalam kebudayaan tersebut ditiadakan, dan mengembangkan unsur-unsur yang positif.

Kedua, untuk melihat dan mengetahui cara mengkontekstualisasikan kebudayaan Toraja bagi pembinaan rohani dalam GBT.

${ }^{1}$ Y. Tomatala, Teologi Kontekstualisasi, (Malang: Gandum Mas, 1993), 40 


\section{Manfaat Penulisan}

Pertama, untuk menjadi salah satu acuan bagi para penginjil/hamba Tuhan dalam GBT khususnya yang melayani di Tana Toraja, di samping Firman Allah dalam meningkatkan kehidupan rohani warga gereja.

Kedua, melalui tulisan ini diharapkan dapat dipakai sebagai perangsang bagi para hamba Tuhan yang tengah melayani dalam GBT di Tana Toraja untuk mendiskusikan lebih lanjut tentang cara memanfaatkan kebudayaan suku Toraja agar dapat menemukan cara yang lebih efektif untuk pembinaan rohani GBT pada masa kini dan yang akan datang.

\section{METODOLOGI PENELITIAN}

\section{Gambaran Umum Lokasi Survei}

\section{Sejarah Berdirinya Badan Persekutuan GBT}

Pada bulan Maret 1957, beberapa hamba Tuhan yang tergabung dalam Gereja Bethel Injil Sepenuh (GBIS), yang sudah mengikuti Pelajaran Tabernakel yang diajarkan oleh Mr. van Gessel bersepakat untuk membentuk suatu organisasi/ jemaat baru, yang diprakarsai oleh Pdt. Gershom Soetopo (Dh Poo Gwan Sien). Niat baik mereka yang merindukan penjabaran "Pelajaran Tabernakel", Tim GMPETAS. Tim ini kemudian menunjuk sebuah Panitia untuk sebuah pertemuan dengan maksud untuk mengintensifkan niat demi perluasan Pelajaran Tabernakel, dengan menunjuk Pdt. Gong Hong Sing sebagai ketua, dan Pdt. Marthen Luther Sambira sebagai penulisnya.

Pada tanggal 29 Mei 1957, di Jl. Mojopahit No. 43-45, gereja dan rumah Pdt Gerson Soetopo, terjadilah pertemuan para pendeta lebih dari 70 orang dan sekaligus meresmikan berdirinya organisasi Badan Persekutuan Gereja Bethel Tabernakel, disingkat: BP GBT. Pertemuan ini sekaligus menunjuk Pengurus Harian Umum (disingkat PHU) sementara dengan maksud untuk mempersiapkan Kongres I.

Pada tanggal 31 Mei 1957, organisasi BP GBT didaftarkan ke pemerintah Republik Indonesia, cq, Kantor Departemen Agama Provinsi Jawa Timur di Surabaya: Kemudian pada tanggal 21 Juni 1957, BP GBT mendapatkan pengakuan Pemerintah Republik Indonesia, dengan Surat Keputusan Kantor Departemen Agama No. II/KA/1957.

Pada tanggal 04-05 September 1957, berlangsung Kongres I Badan Persekutuan Gereja Bethel Tabernakel seluruh Indonesia, di Surabaya dengan membentuk/ memilih Pengurus Harian Umum permanen dengan masa bakti 2 (dua) tahun.

Sampai sekarang ini Badan Persekutuan GBT dengan perkembangan yang cukup baik, telah tersebar di 25 provinsi di Negara Republik Indonesia, dengan jumlah pejabat gereja sebanyak 1.145 orang, tempat ibadah berjumlah 882 tempat, dengan 96.724 jiwa/orang anggota jemaat yang ada di 25 provinsi yang ada di Indonesia. Jumlah yang tercatat ini adalah hasil Mubes ke-18 yang diadakan pada bulan Oktober 2004 yang lalu. Dalam laporan-laporan pengurus daerah, sudah ada lagi pertambahan, baik untuk pejabat gereja, tempat ibadah maupun anggota jemaat.

Setiap jemaat BP GBT setempat, berdiri secara otonom penuh, dan ini merupakan ciri pemerintahan gereja mula-mula di zaman Kisah Para Rasul.

\section{Jenis Penelitian}

Jenis penelitian ini adalah jenis penelitian kualitatif. Penelitian kualitatif adalah jenis penelitian yang menghasilkan penemuan-penemuan yang tidak dicapai dengan menggunakan prosedur-prosedur statistik atau dengan cara kuantitatif lainnya. ${ }^{2}$

\footnotetext{
${ }^{2}$ Basrowi \& Sudikin, Metode Penelitian Kualitatif. (Surabaya: Insan Cendekia, 2002), 1
} 
Prosedur penelitian kualitatif dalam karya ilmiah ini berpedoman pada buku Pengantar Riset Kuantitatif \& Kualitatif, karya Andreas B. Subagyo. Menurut Andreas B. Subagyo,." Dalam penelitian kualitatif, populasi dan sampling tidak ada. Yang ada adalah tempat penelitian atau partisipan (apa/siapa yang diteliti). Yang dimaksud dengan tempat penelitian atau partisipan ialah hal-hal mengenai badan, kantor, organisasi (pelayanan utamanya, struktur organisasinya, kliennya), masyarakat (ukuran dan profilnya), dan isuisu lain yang berkaitan dengan penelitian". ${ }^{3}$ Metode pengumpulan data kualitatif dapat dilakukan dengan metode observasi dan penelitian dokumen, atau variasi dari metodemetode tersebut yang sesuai dengan penelitian kualitatif. Analisis data kualitatif dapat dilakukan dengan teknik deskripsi, analisis dan interpretasi.

Penelitian dilakukan dengan wawancara terbuka, artinya pertanyaan tidak terstruktur, hanya tema pembicaraan tetap mengarah pada masalah bagaimana cara mendayagunakan kebudayaan Toraja bagi pembinaan rohani GBT terhadap kebudayaan Toraja.

\section{Waktu dan Tempat Penelitian}

Dalam bagian ini, penulis akan menguraikan waktu yang penulis gunakan untuk mengadakan penelitian. Secara garis besar, waktu penelitian lapangan dilakukan pada 28 Maret 2009 sampai 20 Mei 2009.

Penelitian ini diadakan di kalangan GBT di Tana Toraja dalam rangka mencari data tentang sikap dan pandangan GBT terhadap kebudayaan suku Toraja. Selanjutnya data yang terkumpul dijadikan sebagai dasar untuk membuat suatu rancangan pengkontekstualisasian suku Toraja, untuk pembinaan kerohanian dalam GBT di Tana Toraja.

Sekalipun tujuan penelitian ini hanya dimaksudkan untuk pembinaan kerohanian dalam GBT di Tana Toraja, akan tetapi guna memperoleh data yang lebih akurat, maka penulis juga mewawancarai beberapa hamba Tuhan, baik yang melayani di Tana Toraja maupun di luar Tana Toraja.

\section{Teknik Pengumpulan Data}

Dalam upaya penulisan ini dan untuk memperoleh data dalam pelaksanaan penelitian di lapangan, maka digunakan beberapa teknik pengumpulan data sebagai berikut:

\section{Penelitian Lapangan}

Pertama, observasi, metode observasi dilaksanakan dengan cara penulis turun langsung ke lapangan mengambil semua data dari informasi yang tepat mengenai pokokpokok yang menonjol dalam kebudayaan suku Toraja.

Kedua, interview, yaitu penulis melakukan wawancara langsung dengan responden, tatap muka. Penulis menggunakan metode wawancara untuk mengumpulkan data dalam penelitian, dengan langsung menyampaikan pertanyaan secara lisan kepada responden. Teknik wawancara dilakukan secara tidak terstruktur. Tujuannya adalah supaya responden dapat mengemukakan pendapatnya secara leluasa sehingga diperoleh informasi sebanyak-banyaknya mengenai pokok-pokok yang menonjol dalam kebudayaan suku Toraja. Hasil wawancara dikutip langsung karena wawancara dilakukan dalam bahasa daerah dan peneliti menggunakan alat perekam yang memungkinkan untuk mengutip pernyataan responden ke dalam bahasa Indonesia lalu menulisnya dalam catatan khusus.

\footnotetext{
${ }^{3}$ Andreas B. Subagyo, Pengantar Riset Kuantitatif \& Kualitatif (Bandung: Kalam Hidup, 2004),
} 


\section{Studi Kepustakaan}

Yang dimaksud dengan studi kepustakaan ialah penulis mengadakan penelitian di perpustakaan Sekolah Tinggi Theologi Jaffray Makassar, serta mencari sumber-sumber informasi melalui buku-buku perpustakaan, majalah-majalah, surat kabar, dan brosurbrosur yang ada kaitannya dengan materi yang sedang dibahas, untuk mencabut semua data dari informasi yang dijadikan bahan lengkap teori untuk literatur.

\section{Teknik Analisis Data}

Data yang terkumpul melalui penelitian dianalisis dengan beberapa teknik. Secara spesifik teknik yang dipakai adalah sebagai berikut: Pertama, deskripsi: yaitu data dari informasi yang tepat mengenai pokok-pokok yang menonjol dalam kebudayaan suku Toraja, yang dapat dikontekstualisasikan untuk pembinaan kerohanian GBT di Tana Toraja, dianalisis dengan cara menguraikan atau memaparkannya dalam bentuk kalimat. Kedua, interpretasi: Data dari informasi yang tepat mengenai pokok-pokok yang menonjol dalam kebudayaan suku Toraja, yang dapat dikontekstualisasikan untuk pembinaan kerohanian GBT di Tana Toraja, dianalisis dengan cara membahas pertanyaan terhadap konteks dan makna sebagai kelanjutan dari penemuan. Ketiga, deduksi induksi: Data dari informasi yang tepat mengenai pokok-pokok yang menonjol dalam kebudayaan suku Toraja dianalisis dengan cara memaparkan bukti-bukti yang diperoleh, lalu dari bukti-bukti tersebut kemudian dibuat suatu kesimpulan.

\section{HASIL PENELITIAN DAN PEMBAHASAN}

Kebudayaan suku Toraja adalah segala sesuatu yang terakumulasi dalam aluk, adat, pemali yang dinyatakan dalam pergaulan dan kehidupan orang Toraja sehari-hari. Melalui kehidupan itu, orang Toraja dapat membina hubungan yang akrab antara manusia dengan Tuhannya, manusia dengan sesamanya dan antara manusia dengan alam lingkungannya. Berdasarkan ketiga hubungan tersebut, terlihat adanya keteraturan tingkah laku dan hasil kelakuan orang Toraja terjelma dalam suatu tradisi, seperti adanya keteraturan dalam menyembah Puang Matua dan menyembah "Tiga Oknum Dewa”, adanya keteraturan sikap dalam interaksi dan komunikasi antara orang tua dan anak, antara pemerintah, tokoh adat dan tokoh masyarakat dengan rakyat, antara keempat Tana, dan keteraturan dalam mengolah alam dan lingkungan sebagai tempat upacara dan kegiatan sehari-hari lainnya. ${ }^{4}$

Dari berbagai unsur kebudayaan ini, yang bersifat netral dan segaris dengan Firman Allah dapat dikembangkan dan dipakai sebagai sarana untuk mengkomunikasikan Injil dan membina rohani gereja. Tetapi unsur kebudayaan yang bertentangan dengan Firman Allah, tidak boleh dikembangkan, baik dalam rangka pembinaan rohani gereja maupun untuk penginjilan.

\section{Konsep Penyembahan}

\section{Konsep Penyembahan Kepada Puang Matua}

Menurut kepercayaan Aluk Todolo, Tuhan yang tertinggi adalah Puang Matua, yang disebut sebagai: Pertama, Puang To Kaubanan, Puang tang tileluk, artinya Tuhan yang tetap ada selama-lamanya dan tidak pernah berubah. Kedua, Puang To tumampa tolino, rumendu tau mate, ungkombong angga maritik, artinya Tuhan yang menciptakan manusia dan segala sesuatu. Ketiga, Puang torro mamase unnisung sa'palabuda, artinya Tuhan yang pengasih dan penyayang, pantang menyebut nama-Nya pada sembarang waktu dan peristiwa. Keempat, Puang tang dirandan kanan kairinna, artinya Tuhan yang tidak terhampiri. ${ }^{5}$ 1994), 8

${ }^{4}$ M. Paranoan, Rambu Solo. (Upacara Kematian orang Toraja), Rantepao: percetakan Sulo, ${ }^{5}$ Ibid, 4 
Penganut agama Kristen juga mengakui bahwa Tuhan Allah (Allah Bapa) adalah Allah Yang Tertinggi (Mazmur 2:4; 113:5; Ayub 22:12; Lukas 2:14), Allah yang kekal dan tidak pernah berubah (Ibrani 13:8; Mazmur 102:26-28), Tuhan Yang Pengasih dan Penyayang (Yohanes 3:16; I Petrus 3:9; Kejadian 22:12; I Yohanes 4:10,19) dan Tuhan yang tidak terhampiri karena Dia Allah Yang Mahakudus (Yesaya 6:3; Mazmur 22:4; Yohanes 17:11; I Petrus 1:15,16).

Hal ini menunjukkan, bahwa pada dasarnya pemahaman Aluk Todolo terhadap Puang Matua segaris dengan pemahaman kekristenan. Berarti bahwa konsep ini dapat dipakai dalam pembinaan rohani gereja dengan menjelaskannya berdasarkan ajaran Iman Kristen yang percaya kepada Allah Yang Esa.

Karena itu, hamba Tuhan sebagai pembina rohani, wajib menjelaskan kepada orang yang dibina melalui pendekatan secara pribadi atau ibadah di dalam dan di luar gereja, bahwa Tuhan Allah yang disembah orang Kristen, disembah bukan lagi dengan menggunakan binatang sebagai persembahan utama, melainkan melalui kehidupan seseorang menyembah kepada Allah di dalam roh dan kebenaran (Yohanes 4:24). Seperti halnya dikatakan Paulus bahwa persembahan yang benar adalah mempersembahkan tubuh sebagai persembahan yang kudus dan berkenan kepada Tuhan (Roma 12:1).

\section{Konsep Penyembahan Kepada Tiga Oknum Allah}

Penganut Aluk Todolo percaya kepada "Tiga oknum allah", dalam bahasa Toraja disebut "Puang Titanan tallu tirindu batu lalikan", yakni: Puang Matua (Tuhan Allah), Deata (Dewa) dan To membalipuang (arwah orang mati).

Sama halnya dengan ajaran kekristenan, menyembah kepada tiga oknum Allah yang disebut "Allah Tritunggal", "Allah Bapa, Allah Anak (Yesus Kristus) dan Allah Roh Kudus, tetapi ketiganya adalah Esa (Kejadian 1:26; Ulangan 6:4; Matius 3:16,17; 28:19; II Korintus 13:13). Tetapi perlu diketahui bahwa sasaran penyembahannya berbeda dengan Aluk Todolo.

Telah dijelaskan di atas, bahwa pemahaman Aluk Todolo tentang "Puang Matua" sebagai oknum pertama segaris dengan pemahaman kekristenan. Kemudian terjadi penyimpangan, seperti Anak Allah (Yesus Kristus) sebagai Juruselamat diganti dengan deata (dewa) oleh Aluk Todolo, sehingga untuk menyembahnya mereka melalui bendabenda, seperti batu, pohon, dan mata air yang dianggap ada dewanya.

Hal ini dapat digunakan untuk mengalihkan kepercayaan Aluk Todolo kepada Tuhan Yesus Kristus sebagai satu-satunya Juruselamat, “... karena di bawah kolong langit tidak ada nama lain yang diberikan kepada manusia yang olehnya manusia dapat diselamatkan, kecuali melalui Tuhan Yesus" (Kisah Para Rasul 4:12).

Dengan demikian konsep ini dapat digunakan untuk pembinaan rohani gereja, dalam menjelaskan Allah Tritunggal bagi jemaat dengan meluruskan konsepnya dan memberi arti yang baru sesuai ajaran Kristen.

Oleh karena itu, dalam rangka pembinaan rohani jemaat, perlu dijelaskan bahwa Allah Tritunggal yang dikenal oleh orang Kristen tidak tinggal di tempat-tempat yang dianggap keramat oleh manusia, seperti pada batu, pohon dan mata air, melainkan tinggal di dalam hati manusia (Lukas 17:21). Dan para dewa tidak dapat menyelamatkan manusia, hanya melalui Yesus Kristus manusia memperoleh keselamatan, sebab hanya Dia satusatunya jalan, kebenaran dan kehidupan (Yohanes 14:6). 


\section{Upacara Rambu Tuka' (Pengucapan Syukur)}

Dalam Aluk Todolo, upacara "rambu tuka" adalah upacara pengucapan syukur yang ditujukan kepada Puang Matua (Tuhan Allah), deata (dewa) dan to membali puang (arwah leluhur) dengan memotong ayam, babi atau kerbau sebagai persembahan. Upacara ini dilakukan untuk mensyukuri segala berkat pemeliharaan para dewa. Di samping itu, upacara ini juga dilakukan dengan maksud memohon berkat dan keselamatan kepada para dewa, sebab penganut Adat Todolo, yakin bahwa para dewa yang disembah itu sanggup menyelamatkan.

Dalam kekristenan upacara "rambu tuka" sama dengan ibadah pengucapan syukur. Perbedaannya dengan Aluk Todolo adalah pada sasaran pengucapan syukur. Orang Kristen mengucap syukur kepada "Allah Tritunggal Yang Esa" atas segala kasih karunia-Nya (I Tawarikh 16:34).

Mengucap syukur bagi orang Kristen merupakan salah satu perintah Allah, "Mengucap syukurlah dalam segala hal, sebab itulah yang dikehendaki Allah dalam Kristus Yesus bagi kamu" (I Tesalonika 5:18) dan mempunyai pengertian yang sangat dalam, yaitu menghormati Allah (Mazmur 50:23; 40:6). Orang Kristen mengakui bahwa hanya ada satu Allah yang kepada-Nya mereka mengucap syukur, sebab Dia Allah di atas, di dalam dan oleh semuanya (I Korintus 8:5,6; Efesus 4:5,6).

Dengan demikian, upacara "rambu tuka" ini dapat digunakan untuk pembinaan rohani GBT di Tana Toraja, bahwa pengucapan syukur merupakan bagian ibadah orang Kristen yang sangat penting. Hal mengucap syukur ini dapat dilaksanakan dalam bentuk puji-pujian dan doa atau dalam bentuk pesta yang sederhana ataupun pesta yang besarbesaran sesuai tingkat kemampuan masing-masing.

Dalam kaitannya dengan pembinaan rohani, hamba Tuhan harus mendekati dan menuntun jemaat, baik melalui dialog maupun persekutuan-persekutuan jemaat, bahwa hal mengucap syukur merupakan bagian penting dari kehidupan setiap orang. Sebagai orang Kristen dalam hidupnya setiap saat dan dalam situasi bagaimana pun harus senantiasa mengucap syukur kepada Allah, sebab itulah yang dikehendaki Allah bagi setiap umat-Nya.

\section{Upacara Rampanan Kapa' (Pernikahan)}

Pernikahan dalam Aluk Todolo sangat dihargai dan dihormati, karena menurut pemahaman penganut Aluk Todolo, bahwa Allah sendiri yang memulai pernikahan itu. Hal ini dapatlah dipakai untuk pembinaan rohani GBT di Tana Toraja karena sejalan dengan ajaran Alkitab.

Memang pernikahan yang dimaksud dalam Aluk Todolo berbeda dengan pernikahan yang dimaksud dalam Alkitab. Namun konsep mereka tinggal diluruskan dengan menjelaskan tentang pernikahan yang dilaksanakan oleh Tuhan Allah sendiri di taman Firdaus antara Adam dan Hawa menurut Kejadian 2:18, 21, 24.

Pernikahan dalam Aluk Todolo memakai Tana dengan maksud supaya jangan terjadi perceraian. Tetapi pada kenyatannya orang masih bisa cerai sekalipun memakai tana sebagai patokan. Apabila terjadi perceraian, maka yang melanggar harus membayar kapa berupa kerbau atau babi kepada suami atau isteri yang diceraikan. Suami/isteri yang menerima kerbau atau babi sebagai bayaran dari mereka yang menceraikannya, dalam bahasa Toraja dinamakan Todikapa'i (suami/isteri yang mendapat bayaran karena diceraikan). Ketentuan kapa berdasarkan tana, misalnya tana' bulaan (kaum bangsawan) harus membayar 24 ekor kerbau kepada suami/isteri yang diceraikan itu sebagai kapa' nya (ganjarannya), sedangkan dalam kekristenan, perceraian tidak diperbolehkan sama sekali karena tidak dikehendaki oleh Allah. Tuhan Yesus berkata dengan tegas, "Demikianlah mereka bukan lagi dua, melainkan satu. Karena itu, apa yang telah dipersatukan Allah, tidak boleh diceraikan manusia" (Matius 19:6; Markus 10:9). Kecuali mautlah yang 
menceraikan suami isteri itu. Selama masih hidup, suami isteri tetap terikat satu dengan yang lain (I Korintus 7:10-11,39; Roma 7:2,3).

Mengenai kapa sebagai jaminan dan ikatan pernikahan, tidak perlu bagi seorang Kristen, karena jaminan itu tidak lebih berat daripada jaminan kasih Kristus yang melampaui segala ikatan apa pun di dunia ini.

Dalam membina jemaat, hamba Tuhan harus memberikan tuntunan dan pemahaman yang jelas tentang perkawinan menurut Alkitab, sebab umumnya orang Toraja sekalipun sudah Kristen masih memahami pernikahan itu sesuai paham Aluk Todolo yang mengizinkan perceraian sesudah pernikahan yang sangat bertentangan dengan ajaran Alkitab.

Jadi, hamba Tuhan harus menjelaskan melalui persekutuan Jemaat atau mendekati secara pribadi khususnya bagi yang akan menikah, dan menuntun mereka sesuai ajaran Alkitab, bahwa pernikahan menurut Alkitab adalah kehendak Allah. Manusia tidak boleh menceraikannya dengan alasan dan jaminan apa pun di dunia ini. Kasih Kristuslah sebagai ikatan dan jaminan dalam pernikahan.

\section{Pemali-pemali (Larangan)}

Pemali (larangan) agama dan adat pada dasarnya merupakan etika, baik dalam aluk todolo maupun dalam Kekristenan. Dalam aluk todolo etika tidak lain adalah pessiparan Toraya. Jadi, pemali dalam hal ini dapat dipakai untuk pembinaan rohani gereja di Tana Toraja.

Pemali Ussongkan Dapo' (Dilarang Bercerai)

Telah dikemukakan di muka, bahwa pernikahan dalam aluk todolo sangat dihargai, sehingga seseorang dilarang menceraikan suami atau istrinya. Pemali ini dapat diterapkan dalam pembinaan rohani gereja dengan memakai konsep-konsep iman Kristen karena dalam Alkitab tertulis jelas bahwa perceraian itu sangat dilarang. Seorang laki-laki atau perempuan yang sudah mengikat janji dalam suatu nikah kudus, sudah menjadi satu daging (Kejadian 2:18-24; Ibrani 13:4). Oleh karena itu, pernikahan tidak boleh diceraikan (Matius 9:5,6; Markus 10:6-9; Roma 7:3), sebab Allah membenci perceraian (Maleakhi 2:16).

Pemali Ma'pangngan Buni (Dilarang Berzinah)

Larangan ini dapat langsung dipakai untuk pembinaan rohani gereja karena segaris dengan Alkitab. Alkitab sangat melarang perzinahan. Keluaran 20:14, dengan tegas mengatakan, "Jangan berzinah". Pada zaman Perjanjian Lama, orang yang berzinah tidak berhak lagi hidup, sebab orang yang berzinah itu dilempari batu sampai mati. Dalam Perjanjian Baru, selain kematian, perzinahan juga merupakan salah satu dosa yang dapat menyebabkan perceraian dalam pernikahan. Itulah sebabnya Allah memerintahkan, "Seorang istri atau suami tidak boleh menceraikan suaminya atau istrinya (I Korintus 7:10,11).

Pemali Boko (Dilarang Mencuri). Alkitab juga sangat melarang pencurian. Keluaran 20: 15 mengatakan, "Jangan mencuri". Mencuri adalah mengambil milik orang lain menjadikan miliknya sendiri secara tidak adil. Dalam larangan ini terkandung tujuan yang positif untuk menghargai milik orang lain dan menghormati haknya.

Pemali Ma'pakena-Kena (Dilarang Berdusta)

Pemali ini pula sangat cocok untuk pembinaan rohani gereja, karena sejalan dengan Alkitab. Dalam Keluaran 20:16, Tuhan Allah memberi peringatan kepada bangsa Israel, "Jangan mengucapkan saksi dusta terhadap sesamamu". Demikian pula dalam Efesus 4:25, “... Buanglah dusta dan berkatalah benar..." Merupakan suatu peringatan bagi setiap orang untuk berhenti berbuat dusta, sebab orang yang dusta bibirnya adalah kekejian bagi Tuhan (Amsal 12:22).

Dengan demikian pemali-pemali di atas dapat diterapkan dalam pembinaan rohani gereja karena sesuai dengan ajaran Kristen dengan menjelaskannya menurut Firman Allah bukan berdasarkan pemahaman aluk todolo. 
Jadi, hamba Tuhan perlu menjelaskan dalam persekutuan-persekutuan jemaat, baik di dalam maupun di luar gereja atau melalui pendekatan secara pribadi bagi jemaat, bahwa pemali-pemali kekristenan bila dilanggar hukumannya bukan dari para dewa atau manusia dengan mempersembahkan binatang sebesar pelanggarannya, tetapi Allah sendiri yang akan menghakimi orang yang melanggar ketentuan hukum Allah setimpal dengan perbuatannya.

\section{Tongkonan}

Tongkonan adalah lambang persekutuan dan sumber kepemimpinan. Tongkonan melambangkan persekutuan keluarga yang bertanggung jawab atas keharmonisan kehidupan keluarga, baik persekutuan keluarga darah daging maupun persekutuan masyarakat. $^{6}$

Dalam aluk todolo jelas ada keterikatan dalam tongkonan. Misalnya, seseorang yang tergolong anggota tongkonan harus "manggiu" "(iuran wajib bagi setiap anggota tongkonan) karena merupakan kewajiban, tetapi kewajiban yang terbatas hanya pada keluarga darah daging. Dapat dikatakan, bahwa keterikatan dalam hal ini adalah keterikatan kasih filea.

Dalam kekristenan mempunyai keterikatan yang tidak terbatas, bukan hanya pada tongkonan, tetapi lebih dari itu. Keterikatan yang dimaksud di sini adalah keterikatan dalam kasih Krsitus (kasih Agape), sebab kasih Kristus mencakup seluruh bangsa (Efesus 3:8; Kolose 3:14).

Dengan melihat nilai-nilai yang terkandung dalam "Tongkonan", maka gereja dapat dikatakan sebagai tongkonan baru, yaitu "Tongkonan orang Kristen". Inti persekutuan baru ini adalah Yesus Kristus, karena Dialah pendiri persekutuan baru itu (Kisah. 2:46). Gereja dalam bahasa Toraja dinamakan "Tongkonan Layukna Puang Matua" (rumah pusaka Allah), sedangkan warga gereja adalah anggota tongkonan atau keluarga Allah (Efesus 2:9) dan milik Kristus (1 Kor. 3:9). Setiap orang dalam persekutuan jemaat mempaunyai hak dan tanggung jawab terhadap Tuhan dan terhadap jemaat.

Jadi, tongkonan sebagai persekutuan baru dalam masyarakat Toraja, mempunyai peranan sebagai persekuatuan yang erat. Sebab itu, dalam rangka pembinaan rohani jemaat, yang ditekankan dalam persekutuan jemaat sebagai keluarga Allah adalah penting sebab persekutuan Kristen lebih dari persekutuan tongkonan, sebab dalam persekutuan keluarga Allah tidak mengenal tingkatan sosial masyarakat, yaitu antara tuan dan budak sebagaimana yang terdapat di kalangan masyarakat Toraja.

\section{Sikap Gotong-Royong}

Ciri utama dari sikap gotong-royong bagi suku Toraja adalah saling membutuhkan dan saling menolong teristimewa di bidang kerja sawah atau dalam menghadapi rambu tuka' dan rambu solo'. Gotong-royong ini juga merupakan lambang persekutuan orang Toraja, dan yang menjadi ikatan dalam gotong-royong ini adalah kasiturusan (persetujuan bersama).

Dengan demikian, nilai budaya gotong-royong ini dapat dipakai untuk pembinaan rohani GBT di Tana Toraja karena segaris dengan ajaran Kristen. Alkitab mencatat: "Bertolong-tolonganlah menaggung bebanmu! Demikianlah kamu memenuhi hukum Kristus" (Galatia 6:2; Mazmur 133:1-3). Karena itu, pembina rohani, harus membimbing dan menuntun orang-orang yang dibina melalui persekutuan jemaat, supaya mereka saling menolong dan melayani tanpa mengharapkan imbalan atau jasa. Dengan kata lain, mengarahkan jemaat untuk mendahulukan kepentingan umum dari kepentingan individu.

${ }^{6}$ Pdt. Th. Kobong., Makalah: Kepemimpinan Tongonan Dalam Rangka Transformasi Kultural, (Buku Hasil Keputusan Sidang Sinode Am XVIII Gereja-Gereja Toraja, Juni 1988). 


\section{Saling Memberi}

Saling memberi bagi orang Toraja merupakan salah satu tanda persekutuan. Orang sering memberi bukan hanya dari segi ekonomisnya untuk membantu keluarga atau seseorang yang kekurangan, tetapi terlebih sebagai tanda penghargaan serta ungkapan hubungan yang akrab dan rasa berada dalam satu persekutuan.

Nilai persekutuan dalam kehidupan orang Toraja begitu tinggi. Prinsip persekutuan itu berbunyi, "Misa' kada dipotuo, pantan kada dipomate", yang mempunyai makna sama dengan peribahasa, "Bersatu kita teguh, bercerai kita runtuh". Hal ini dapat dikontekstualisasikan bagi pembinaan rohani GBT di Tana Toraja, sebagaimana telah dipraktikkan oleh sidang jemaat mula-mula (Kisah. 4:32-37). Yang perlu ditekankan bahwa dalam konteks persekutuan gereja, saling memberi itu jangan diformalkan sebagai hutang-piutang. Hendaknya pemberian itu dengan tulus hati tanpa mengharapkan balasan dari sesama (Matius 6:3-4). Tuhan Yesus berkata: “... lebih berbahagia memberi daripada menerima" (Kisah. 20:35).

Dalam membina rohani jemaat, perlu lebih ditekankan hal saling memberi di antara sesama jemaat khususnya, tanpa mengharapkan imbalan, tetapi dilakukan dengan tulus hati, sebagaimana Tuhan Yesus lebih menekankan hal memberi. Dengan demikian, jemaat dituntun dan diarahkan untuk berkorban bagi pekerjaan Tuhan di dalam atau di luar gereja.

\section{KESIMPULAN}

Pertama, kebudayaan adalah hasil cipta manusia yang mempengaruhi segala segi kehidupan manusia sendiri. Kebudayaan suatu masyarakat merupakan identitas masyarakat itu yang oleh para warganya dijadikan sebagai pedoman dalam kehidupan sehari-hari. Oleh karena itu, kebudayaan mempunyai fungsi memperkokoh solidaritas masyarakat yang dalam hal ini meliputi memperkokoh persatuan dan kesatuan masyarakat dan meningkatkan taraf hidup masyarakat secara keseluruhan.

Kedua, kebudayaan suku Toraja dilatarbelakangi oleh Aluk Todolo (agama suku Toraja), yaitu suatu agama yang percaya kepada tiga oknum allah, yakni "Puang Matua" (Allah Sang Pencipta), "deata" (dewa-dewa) dan "to membali puang" (arwah orang mati).

Ketiga, Aluk, adat dan kebudayaan suku Toraja merupakan satu kesatuan yang kaitmengait dan sulit dipisahkan dari yang lain. Sebab itu, adat dan kebudayaan tidak dapat dipisahkan dari keyakinan Aluk Todolo, maka gereja atau orang-orang Kristen di Toraja wajib menguji setiap adat kebudayaan apakah sesuai dengan kehendak Tuhan atau tidak.

\section{Saran-Saran}

Berikut ini penulis akan memberikan beberapa saran sehubungan dengan pembinaan kerohanian GBT dalam konteks kebudayaan Toraja, semoga menjadi berkat dalam pelayanan GBT di Tana Toraja. Pertama, bahwa dalam mempelajari kebudayaan adalah suatu tugas suci. Sebab itu, setiap hamba Tuhan (pembina rohani) hendaknya mempunyai pemahaman yang benar tentang kebudayaan dan kerohanian serta hubungannya satu sama lain, kemudian menjelaskan hal ini kepada jemaat yang dilayani. Kedua, kebudayaan suku Toraja adalah identitas dan pola hidup orang Toraja. Oleh karena itu, hamba Tuhan utamanya yang melayani di Tana Toraja, hendaknya mengetahui unsur-unsur dalam kebudayaan Toraja, sebab unsur-unsur dalam kebudayaan ini ada yang bersifat menentang kebenaran Firman Allah, ada yang bersifat netral dan ada pula yang segaris dengan Firman Allah. Yang bertentangan dengan kebenaran Firman Allah harus ditinggalkan, sementara yang netral dan segaris dengan Firman Allah dapat dikontekstualisasikan dengan cara membarui dan menguduskannya di bawah ketaatan 
kepada Firman Allah agar bertujuan untuk memuliakan nama Tuhan. Ketiga, hendaknya GBT bersifat positif dan selektif, baik dalam hal menolak maupun dalam hal menerima aluk, adat dan kebudayaan. Setiap unsur kebudayaan yang dapat diterima melalui saringan Firman Allah, sebaiknya dikembangkan secara dinamis, sedang yang bertentangan dengan Firman Allah otomatis harus ditolak. Dengan demikian, hamba Tuhan harus berani berkata, "tidak" kepada kebudayaan yang bertentangan dengan Firman Allah dan berkata, "ya" kepada kebudayan yang dapat dialihkan dan diarahkan untuk hormat dan kemuliaan nama Tuhan.

\section{KEPUSTAKAAN}

\section{Buku-Buku}

Basrowi \& Sudikin. Metode Penelitian Kualitatif. Surabaya: Insan Cendekia, 2002.

Kobong, Th, dkk. Aluk, Adat dan Kebudayaan Toraja Dalam Perjumpaan Dengan Injil. Jakarta: Institut Theologia Indonesia, 1992.

Paranoan, M. Rambu Solo' Upacara Kematian Orang Toraja. Rantepao: Percetakan Sulo, 1994. Subagyo, Andreas B. Pengantar Riset Kuantitatif e Kualitatif. Bandung: Kalam Hidup, 2004. Teologi Kontekstualisasi. Malang: Gandum Mas, 1993. 